\section{コロモジラミ及びアタマジラミ成虫 の粉刘に対する抵抗性の研究}

\section{安富和男}

Yasutomi, K. : Studies on the resistance of human body louse and head louse to insecticidal powder

各地で採集したコロモジラミ成虫の $5 \%$ DDT 粉剂及 び $0.5 \% r-\mathrm{BHC}$ 粉䞄に対する抵抗性の相違を比較し,

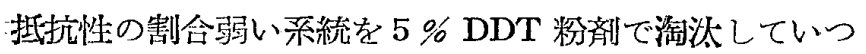
た場合の抵抗性の増大と, DDT との接偊をやめた後の 抵掞性の消失の問題を実験的に検討し，さらに，アタマ ジラミを毛布片に附着させて飼育し，形態的な变化に伴

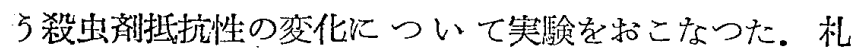
䖧, 北海道留萠郡堌毛町, 青森, 神戸などの諸地方の浮 浪者, 学童より採集したコロモジラミを1代の間, 笑験に 供試可能な数になるよ5に飼育堌殖し， $5 \%$ DDT 粉剂 を, 径 $9 \mathrm{~cm}$ のシャーレの底にしいた濾紙上に種々の薬 量撒布したものに㢺触させ， $25^{\circ} \mathrm{C}$, 暗黑条件下に 24 時 間特いた後死亡率を調查し，薬量一死亡率回帰消線から LD-50を求め, 担抗性を比較した結果, 抵抗性の強い少 統と弱い系統との抵抗性の差は $2: 1$ 程度であつた. $5 \%$

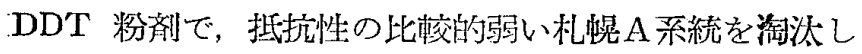
てゆき, 5 代の後, 泡汰しない正常な系統と比較したとこ ろ, LD-50で3.5 倍強い結果を得た，DDT のアセトン

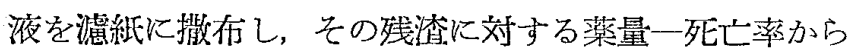
抵抗性を比較した場合とは非常に累り，品質の優れた DDT 粉斉撒布による実験の結果では，担抗性の増大は それほど䖵く認められないまた，5代淘汰した後， DDT と接強することをやめて世代を絽返えせば，抵抗 性は徐々に弱くなつたが，2 代経過した後も，最初から 3 代湟汰したとさよりも抵抗性が強く，接触を停此して 5 代を経過した後も, 正常の札蜆系統より抵抏性が若下 強からた。即ち，抵抗性を堌大するのに要したの々，同 じ世代数を無接触の状態に执いても，抵抗性が最初注ど には弱くならなかつたわけである，神戸市の浮浪者から 採集したアタマジラミを毛布の小片に附着させて $30^{\circ} \mathrm{C}$ の定温器中に括き，日に2回人の上膊部より吸血させる コロモジラミの飼育法で飼育すると, 形態的に次第にコ ロモジラミに近づき，5代を経過した後には，コロモジ ラミと区別出来ない外部形態を示した。アタマジラミの DDT 粉剂に対する抵抬性は極めて弱いが，形態的にコ ロモジラミに接近するにつれて, 抵摭性も过第に増大 し，5世代の後には，抵抗性の弱いコロモジラミ程度の 強さになつたことは興味ある事箺だと考える。各哳で採
集したコロモジラミの $0.5 \%$ r-BHC 粉風に対する抵抗 性には大差がなかつたが，r-BHC においては接触後 24 野間経過しても，苦悶状態を続けているものが多く，薬 量一死亡率回帰直線の傾斜は極めて緩かになつた。

(子研掌生昆虫)

示說

\section{近畿地方産ニホンジカに対する恙 虫の集団寄生例について}

$\begin{array}{cccc}\text { 榎本 } & \text { 義文 } & \text { 德永 } & \text { 孝一 } \\ \text { 加納 } & \text { 六郎 } & \text { 熊田 } & \text { 信夫 } \\ \text { 金子 } & \text { 清俊 } & \end{array}$

Enomoto, Y., Tokunaga, K., Kano, R., Kumada, N. \& Kaneko, K. : Tsutsugamushi on Japanese deer

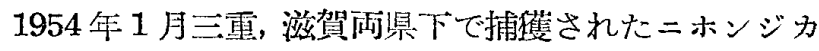
(Cerus nippon Temminck, 1837) 計 4 頭（三需座 3 頭，滋賀産 1 頭）の外部奇生虫を調査したところ意外に も多数の恙虫幼虫の吸湆を認めた。吸羙部位は口周，頸 部, 肩部, 腰部, 眼の周国，上膊，脛部等で，この順に 多く，重慮数乃の橙色乃至橙赤色の恙虫幼出が恰もアカ カビが発生した様な観を是して吸着していた。各部位よ り無作為に多数の虫体を採取し，この中 320 㱜をガム・ クロラール液封入スライド標本として種類の判別を行つ た。この結果滋㖵座 1 頭については Trombicula(Neotrombicula) ichikawai Sasa 近似種 128 㱜, Euschöngastia miyagawai Sasa et al. 1 正, 三央産 3 頭について はT. (N.) ichikawai 近似種合計 84.㱜, E. miyagawai 合計 107 疋を同定することが山来た，次で各部の特徽を 完全に見学る標本を選び，所芫の背甲板標準計測值及び 毛生列等の测定及び観察を行つた所， E. miyagawai と 同定した標本は原記載及び原図と比較すると触䯮第 1 節 腹面に生ずる開毛が羽毛状である他は極めてよく一致し ていたが，T.(N.) ichikawai 近似種については次の諸 点が ichikawai と異つていた。 即ち胴背面毛の配例が原 則として $2,6,8,6, \cdots \cdots て ゙ あ り($ ichikawai の記載は $2,6,6, \cdots \cdots)$ 第 3 列の䍏毛数が異る。標準测定值は 一般に大きく, 特に ASB, PSB, SD 等の背甲板の深さ は ichikawai よりも 15 乃至 $20 \%$ 大であり，又 等の背甲板より生ずる 备種岡毛の長さも夫及約 $20 \%$,

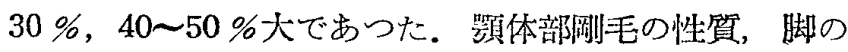
感覚毛の配列等については ichikawai と区別できなかつ た。以上の諸点からこった ichikawai 近似種として報 告するものが，分類上どの椂な取扱いを受るかについて の結論は困難であつて，本種が ichikawai と一致するも 
のであるか, 近緑の $T .\left(N_{.}\right)$nagayoi と ichikawai と

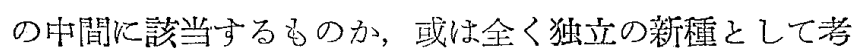
えるべきものであるがついての渗定には慎重を期しれ い.

(東京医科整科大学・医動物)

\section{岐卓縣の意虫について \\ 今井田三三子水町 睛重 古山 幸雄}

Imaida, F., Mizumachi, H. \& Koyama,

Y.: On the Tsutsugamushi

(trombiculid mites) in Gifu Prefecture

昭和 29 年 3 月より 30 年 3 月に亘る 1 年間を通じて岾

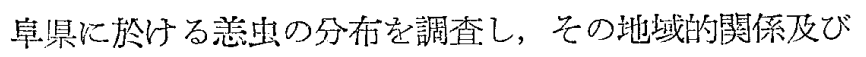

採职地別の恙虫の附䇎状況

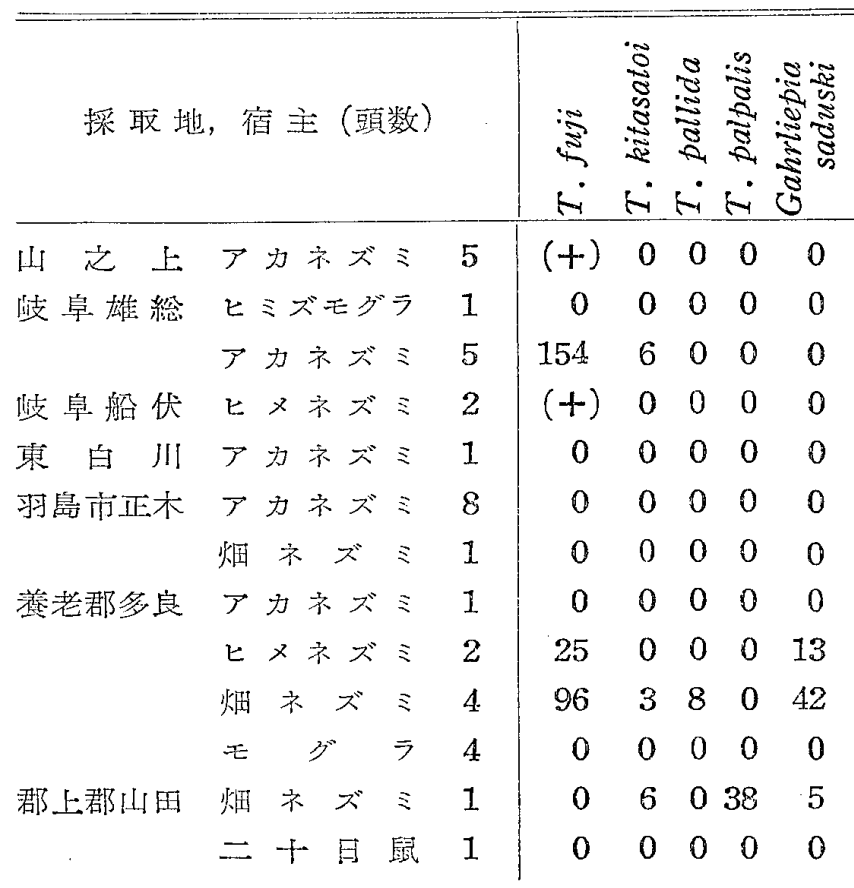

恙虫の季節的消崕

\begin{tabular}{|c|c|c|c|c|c|c|c|}
\hline 月 & 缩 主(頭 & 数） & 㲾 & 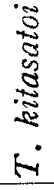 & 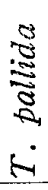 & 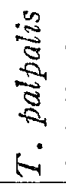 & 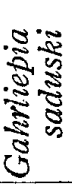 \\
\hline \multirow[t]{2}{*}{ 29年 3} & アカネズ & 7 & $(+)$ & 0 & 0 & 0 & 0 \\
\hline & ヒメネズ & 3 & $(+)$ & 0 & 0 & 0 & 0 \\
\hline 7 & アカネズ & 1 & 0 & 0 & 0 & 0 & 0 \\
\hline \multirow[t]{2}{*}{8} & アカネズ & 2 & 0 & 0 & 0 & 0 & 0 \\
\hline & モ & 4 & 0 & 0 & 0 & 0 & 0 \\
\hline \multirow[t]{3}{*}{11} & アカネズ & 3 & 0 & 0 & 0 & 0 & 0 \\
\hline & 畑 ホ、ズ & 1 & 0 & 0 & 0 & 0 & 0 \\
\hline & ヒメネズ & 1 & 15 & 0 & 0 & 0 & 0 \\
\hline 12 & アウネズ & 5 & 14.0 & 1 & 0 & 0 & 18 \\
\hline
\end{tabular}

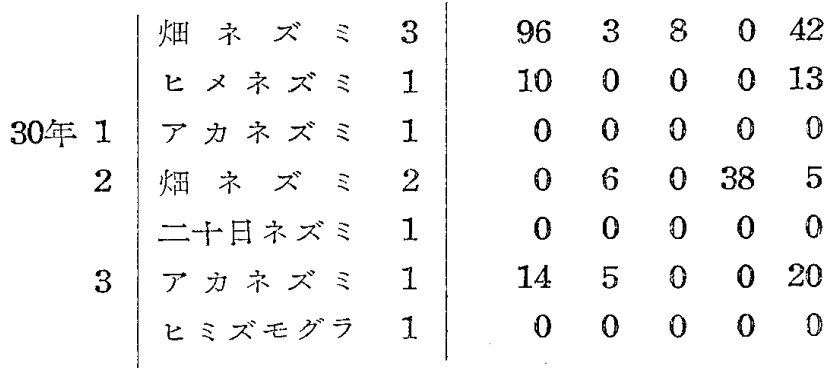

李節的消㔫を観察した。

家爯については3 方所計 16 頭についてしらべたが何 れにも弄虫の附着は認めなかつた。

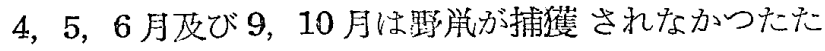
わその間の観察は出来なかつたが，以上により歧早県に は主として冬型の恚安が存在することが明かとなつた。

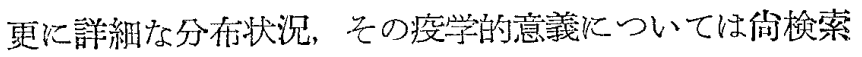
けである。

（攺㚖医科大学・笴生虫）

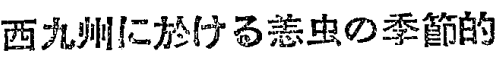 消長について（籍2 報）}

\section{藤 昰 克}

Fujisaki, K.: On the seasonal distribution of trombiculid mites in Western Kyushu

西九州に於ける意出の季節的消長を調べるために，次 の3 所で定期的な採集を行つた。 即方任賀县肥前山口 では，昭利 27 年 6 月から 29 年 5 月まで，每月 2 回，50

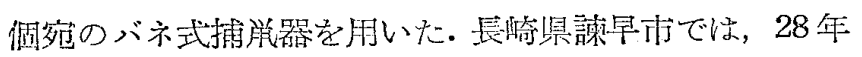

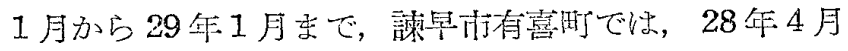
から29年3月屯で, 同様の調查をした。この外西北て

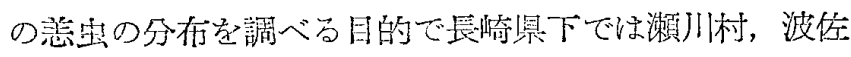
見町，五島，対馬，住賀県下では，小城，松消，麼児島

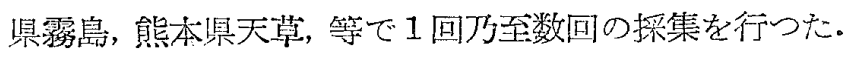
野単類総数 289 頭でアカネズミ234頭，ヒメネズミ45 頭，ヒミズェグラ 8 頭，モグラ 1 䁰，ドブネズミ1頭で

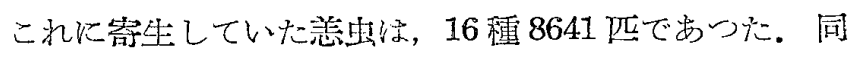
じ日に採れた同種の恙出数兴数で除した平均值によつ て等節的消長学見た。

1）Trombicula fuji；大体年間を避じて採集出来る が，冬多く，悬少ない。最高は 27 年 11 月であるが，10 月から次第に多くなり，3月から少なくなり始める。夏 の6，7，8月は非常に少なく，採れない事が多い，2）

T. kitasatoi； T. fujiに大変良く似ているが最高が低 く，出現期間が長いようである。即ち $T$. fuji に比べ て，业線がなだらかな山孛なしている．3）Gahrliepia saduski；T. fuji 似ているが，数的に少ない地線を画 いている。最高は2月であつた.4) T. kochiensis; 最 